\title{
Large Hemorrhagic Colloid Cyst in a 35-Year-Old Male
}

\section{Yaşındaki Bir Erkekte Büyük Hemorajik Kolloid Kist}

\author{
Neva COCE ${ }^{1}$, Goran PAVLIŠA ${ }^{1}$, Sibila NANKOVIĆ ${ }^{2}$, Antonija JAKOVČEVIĆ ${ }^{3}$, Marina ŠERONJA-KUHAR ${ }^{1}$, \\ Gordana PAVLIŠA ${ }^{4}$ \\ ${ }_{1}$ University Hospital Zagreb, Department of Radiology, Zagreb, Croatia \\ ${ }^{2}$ University Hospital Zagreb, Department of Neurology, Zagreb, Croatia \\ ${ }^{3}$ University Hospital Zagreb, Department of Pathology, Zagreb, Croatia \\ ${ }^{4}$ Special Hospital for Pulmonary Diseases, Intensive Care Unit, Zagreb, Croatia
}

Correspondence address: Neva COCE / E-mail: neva001@gmail.com

\begin{abstract}
Colloid cysts are rare benign tumors of the third ventricle with diverse clinical presentation, which vary from incidentally found cysts to acute death. An uncommon hemorrhage in these cysts is a life threatening complication which can cause obstructive hydrocephalus with acute deterioration of the patient and sudden death. We present a case of 35-year-old man with large hemorrhagic colloid cyst of a third ventricle causing acute obstructive hydrocephalus even though magnetic resonance image with low T2 signal of the cyst suggested its clinically stable nature. Only 3 cases of in vivo diagnosed hemorrhagic colloid cysts have been reported in the literature.
\end{abstract}

KEYWORDS: Colloid cyst, Hemorrhage, Third ventricle, Hydrocephalus

\section{öz}

Kolloid kistler üçüncü ventrikülün nadir benign tümörleri olup tesadüfen bulunan kistlerden akut ölüme kadar çok geniş bir klinik sunum aralığına sahiptir. Bu kistlerde sık görülmeyen bir olay olan kanama obstrüktif hidrosefaliye ve sonuçta hastanın durumunda ani bozulmaya ve ölüme neden olabilen yaşamı tehdit edici bir komplikasyondur. Üçüncü ventrikülde büyük bir hemorajik kolloid kisti olup kistte düşük T2 sinyaliyle manyetik rezonans görüntülemenin klinik olarak stabil bir durum düşündürdüğü akut obstrüktif hidrosefali bulunan 35 yaşında bir erkek sunuyoruz. Literatürde in vivo tanı konmuş sadece 3 hemorajik kolloid kist vakası mevcuttur.

ANAHTAR SÖZCÜKLER: Kolloid kist, Kanama, Üçüncü ventrikül, Hidrosefali

\section{INTRODUCTION}

Colloid cysts are benign lesions which comprise $0.55-2 \%$ of all intracranial tumors and represent $55 \%$ of the third ventricle's lesions (5).

Their magnetic resonance imaging (MRI) appearance is diverse and varies according the cyst content (cholesterol, calcium, hemosiderin), but most are of high signal on T1weighed images and low on T2-weighed images $(10,6,8,3)$. T2- hyperintense colloid cysts are proven to carry higher risk of expansion over time $(4,9)$.

Symptoms associated with colloid cysts are primarily due to increased intracranial pressure.

Rare hemorrhages in these cysts can cause acute obstructive hydrocephalus and sudden death $(4,6,7)$.

We present a 35-year-old male patient with a large hemorrhagic cyst in the third ventricle and symptoms of acute obstructive hydrocephalus.

\section{CASE REPORT}

A 35-year-old male patient was admitted to a county hospital with intensive headache, nausea, transient loss of consciousness and incontinence. He had suffered from headaches, severe weakness and fatigue for several months before admittance.

Computed tomography (CT) revealed a large hyperdense oval mass with patchy rim calcifications in the third ventricle with signs of hydrocephalus. The patient was then transferred to our centre where MRI showed a cystic mass with the largest diameter of $4.6 \mathrm{~cm}$, expanding the third ventricle with stretched pillars of fornix and obstruction of foramina of Monro. It was well-demarcated and markedly hyperintense on T1-weighted images and hypointense on T2-weighted images (Figure 1A, B). The findings were interpreted as a colloid cyst with hemorrhagic content.

The patient was referred to surgery and the cyst was completely removed by the transcallosal approach. The patient tolerated the procedure well and there were no neurological complications. Pathohistological findings of the 

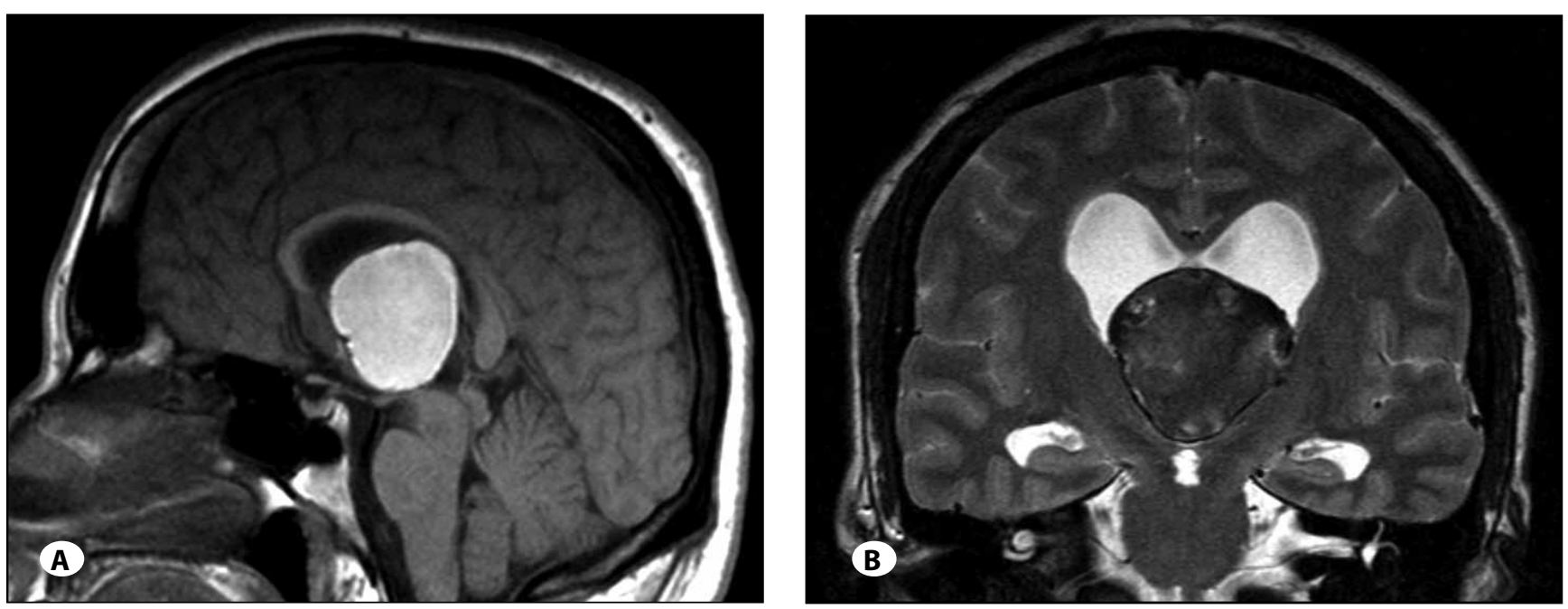

Figure 1: Large cystic mass in the third ventricle, well-demarcated and markedly hyperintense on sagittal T1-weighted image (A) and hypointense on coronal T2-weighted image (B).

resected material confirmed a colloid cyst with subacute and chronic hemorrhage and areas of calcification lining the cyst.

\section{DISCUSSION}

Colloid cysts are congenital lesions, endodermal in origin, classically located in the third ventricle. They contain gelatinous matrix commonly lined by cuboidal and columnar epithelium (4).

The prevalence of these lesions is estimated 1 per 8500 persons with incidence of 1 per 1 million person-years (1), however only a small percentage of them become symptomatic.

If symptomatic, colloid cysts usually produce signs of raised intracranial pressure such as nausea, vomiting, visual disturbance, confusion and cognitive decline, disturbance of balance or gait and paroxysmal headache usually associated with changing head position $(6,7,8)$.

Sudden neurological decline and sudden death have been documented, especially with cysts larger than $1 \mathrm{~cm}$. Acute blockage of cerebrospinal fluid (CSF) with instant brain herniation is one of the proposed mechanisms of sudden death. Another is the disturbance of hypothalamus-mediated cardiovascular reflex control (2).

One of the causes of a sudden foramen of Monro obstruction and consequent increase of CSF pressure may be hemorrhage in the cyst with an acute increase of cyst dimensions (1).

MRI signal of colloid cysts may be variable, and it is shown that those with low T2 signal are less likely to expand $(4,9)$. This case is not typical in that regard, since the cyst was T2 hypointense but unusually large, measuring $4.6 \mathrm{~cm}$. Cysts larger than $3 \mathrm{~cm}$, such as this one, are extremely rare $(5,7)$ and to our knowledge, hemorrhagic content has been reported in only three in vivo cases so far $(5,4,1)$.

This case demonstrates that low T2 signal on MRI images is not necessary a sign of the clinically stable nature of the cyst. MRI appearance itself is not a reliable prognostic sign, since T2 hypointensity may be present with or without hemorrhage. If hemorrhage in the cyst occurs, it is usually the cause of its rapid growth and an acute deterioration of the patient.

\section{ACKNOWLEDGMENTS}

The authors thank Ms. Silvana Giljanovic, MD and Mr. Dinko Nizic, MD for their assistance.

\section{REFERENCES}

1. Beems T, Menovsky T, Lammens M: Hemorrhagic colloid cyst: Case report and review of the literature. Surg Neurol 65: 84-86, 2006

2. Demirci S, Dogan KH, Erkol Z, Gulmen MK: Sudden death due to a colloid cyst of the third ventricle: Report of three cases with a special sign at autopsy. Forensic Science International 189:e33-e36, 2009

3. El Khoury C, Brugieres P, Decq P, Cosson-Stanescu R, Combes C, Ricolfi F, Gaston A: Colloid systs of the third ventricle: Are MR imaging patterns predictive of difficulty with percutaneous treatment? AJNR 21:489-492, 2000

4. Farooq U, Bhatt A, Chang HT: Hemorrhagic Colloid cyst in a 9-year-old girl. Pediatr Neurol 38:443-444, 2008

5. Hamlat A, Casallo-Quiliano C, Saikali S, And M, Brassier G: Huge colloid cyst: Case report and review of unusual forms. Acta Neurochir 146:397-401, 2004

6. Jeffree RL, Besser M: Colloid cyst of the third ventricle: $A$ clinical review of 39 cases. J Clin Neurosci 8:328-331, 2001

7. Mathiesen T, Grane P, Lindgren L, Lindquist C: Third ventricle colloid cysts: A consecutive 12-year series. J Neurosurg 86: 5-12, 1997

8. Nitta M, Symon L: Colloid cysts of the third ventricle. A review of 36 cases. Acta Neurochir 76:99-104, 1985

9. Pollock BE, Schreiner SA, Huston J $3^{\text {rd }}$ : A theory on the natural history of colloid cysts of the III ventricle. Neurosurgery 46:1077-1081, 2000

10. Urso JA, Ross GJ, Parker RK, Patrizi JD, Stewart B: Colloid cyst of the third ventricle: Radiologic patologic correlation. J Comput Assist Tomogr 22:524-527, 1998 